\title{
水土保持对水资源的作用及其影响分析
}

\author{
李超华 樊西杰 \\ 黄河水利委员会三门峡库区水文水资源局 \\ DOI:10.32629/hwr.v4i9.3296
}

\begin{abstract}
[摘要] 随着中国经济的快速发展和城市化进程的推进,我国的水资源问题日益严峻。水资源在我国国 民经济的发展进步中占有重要地位,随着工业化程度不断加快,水资源遭到了不合理的利用,致使水资源 受到了严重的污染, 因此,为了使水资源问题得到缓解, 使生态环境得到改善, 文章分析水土保持措施对水 资源与水环境的影响具有重要意义。
\end{abstract}

[关键词] 水土保持; 水资源; 影响; 作用

中图分类号：S278 文献标识码：A

\section{1 我国水资源和水环境的现状}

从实际情况来看, 我国水资源相对 较贯乏, 南水北调的工程是保证大部分 地区拥有水资源的有所举措, 同时, 我 国人口数量较多, 对于水资源的需求也 更大。以往我国为了取得良好的经济效 益, 一味的进行重工业的发展, 环境的 保护工作并没有得到重视, 从而导致水 资源短缺、水土流失、水污染等问题逐 渐突显出来。工业排水污染和居民用水 污染, 以及受到自然因素的影响, 导致 自然灾害的频繁发生, 比如, 水土流失、 滑坡等, 其给我国生态环境带来极大的

索垂度控制为 $\mathrm{L} / 70$ ( $\mathrm{L}$ 为跨度)。一端 安装主索紧线器, 行程 $1000 \mathrm{~mm}$, 用于调整 主索垂度。

循环索(升降索) 采用 $6 \times 19+\mathrm{fc}-4.2 \mathrm{~mm}$, 断破拉力 $\mathrm{T} j=860 \mathrm{~kg}$, 安全系数 5.6 。根据 循环索的布设型式, 平衡锤为 $200 \mathrm{~kg}$, 并 配套有平衡锤吊杆、吊架各一套。导向 滑轮采用直径 $160 \mathrm{~mm}$, 厚 $25 \mathrm{~mm}$, 配用轴承 8206 , 轴径 $30 \mathrm{~mm}$ 的铸铁滑轮。

\section{(4) 设备安装}

安装工序：塔架组立、主索架设、 导向架及滑轮安装、循环索架设、铅鱼 和平衡锤安装等。施工严格按水文缆道 施工技术要求进行, 高空作业做好安全 保护措施, 错杆防腐处理, 刷底漆后机油 渗黄油。循环索安装, 采用开口式游轮,

危害。

\section{2 水土保持对水资源的影响}

2. 1 通过水土保持措施可以对流域 的产沙数、径流量进行减少, 降低水流当 中的含沙量, 推迟洪峰到来的时间, 减少 洪水的产生, 对产沙和产流两者的关系 进行有效的调整。这样就会对该领域水 循环和水资源量造成一定的影响。

2.2 对水土保持采取科学合理的措 施, 有利于对该区域的水资源量进行较 好的控制, 并且可以对水资源内部结构 进行有效的调整, 降低当前该区域水资 源的污染情况, 有效的增强该区域水资

有平衡锤的布设型式, 循环索安装完成 后调整铅鱼、平衡锤及游轮的相对位置, 安装后进行试运行。

\section{3地下管线保护}

根据物探结果, $1 \mathrm{~m}$ 宽绿化带下有电 力管线, 右岸滨河路下有雨水、污水、燃 气及不明地下管线。塔架基础位于电力 管线下, 施工过程中需对电力管线进行 保护, 确保安全运行。

\section{5 建议}

本文主要介绍了通惠河乐家花园水 文站因附近项目施工导致测流缆道和右 岸塔架损坏, 不能正常运行, 不利于安全 度汛。

通过实地勘察, 明确现有交叉建构 筑物情况, 采用钢筋混凝土承台作为塔
源量的总体质量。

3 水土保持措施对水资源和水

\section{环境的具体作用}

3. 1 农田抗旱能力有所提升。水土保 持会对农田产生影响主要原因就是通过 水土保持措施的使用实现了土壤蓄水能 力以及渗水效率的大幅度提升, 也就是 将土壤自身的适度予以提升。根据之前 的研究结果不难总结出来, 水土保持措 施的有效执行, 可以将土壤自身的适度 提升 $25 \%$ 到 $30 \%$ 之间, 土壤自身的湿度提 升, 对于农作物的种植、生长以及农田自 身抗寒能力的提升有着十分显著的效果,

架基础、钢制塔架, 便于施工维护, 为北 京市安全度汛提供保障。

\section{[参考文献]}

[1]中华人民共和国建设部.建筑结 构荷载规范 [M]. 中国建筑工业出版 社,2006.

[2]水工混凝土结构设计规范 [M]. 中国水利水电出版社,2008.

[3]混凝土结构设计规范 [M]. 中国 建筑工业出版社,2010.

[4]建筑地基基础设计规范 [M].中 国建筑工业出版社,2011.

[5]钢结构设计规范 [M].中国建筑工 业出版社,2017.

[6]水工挡土墙设计规范 [M].中国水 利水电出版社,2007. 
而农作物自身的良好长势也可以做到进 一步降低水土流失, 也就会进一步将水 土保持工作予以提升, 借此来保障土壤 自身的保水以及保土作用得到最为充分 的发挥, 将整个农田的抗旱能力予以进 一步提升。

3. 2 增强植物的抗旱能力。随着我国 农业的持续发展, 农业水平有了有效的 提升, 做好水土保持工作有助于增强植 物的抗旱能力, 有效保障农业的持续发 展, 形成一种良性循环, 使水资源得到高 效的利用。水资源是植物生长的第一要 素, 做好水土保持工作能够为农业生产 提供安全可靠的水源, 随着科学技术的 不断发展, 很多新兴的技术被应用到了 水土保持工作中, 措施越来越先进, 仪器 设备越来越完善, 通过开展科学合理的 水土保持工作, 能够有效提高土地肥力, 植物生长效率有效提升, 实现更高的产 量, 从而进一步拉动了农民的经济效益, 这也有助于新农村建设, 促进我国经济 发展。

3. 3 河流洪峰流量的减少。水土保持 措施能够实现抗洪拦蓄, 其主要是通过 固土保土的方式实现这一目的, 通过控 制河流流量, 使河流的径流量得以改善, 有助于实现河流的循环, 防止一些自然 灾害的发生, 比如, 滑坡、泥石流等。另 外, 通过有效改进河流水道, 使河流洪峰
流量得到减少, 在很大程度上能够实现 河流的下游的保护效果。

\section{4 水土保持的主要措施}

4. 1 工程技术措施。工程技术措施拥 有较强的综合性质, 大多数都是对规定 区域当中的地形进行改变, 从而实现对 水土进行相应的拦截。通过这样的方式 能够促使土壤的蓄水能力得到相应的加 强, 除此之外, 还可以将一些自然资源, 比如水、阳光、风以及温度等都能够实 现更好的利用, 据此创设一个新型又优 良的生态系统, 避免出现大量的水土流 失。除了上述措施之外, 工程技术措施还 可以经过对工程建设实现对水资源的有 效利用, 比如, 治坡工程、治沟工程以及 水利工程等, 都能够更好地实现水土保 持, 更好地保持生态环境朝着平衡方向 发展。此外在农业灌溉中也可以大力推 广节水技术, 在推动农业现代化的同时, 也能够实现水资源的保护。而水质的改 善除了必要的水土保持手段外, 还需要 借助于净水技术改进, 促进水资源的再 循环。

4. 2 林草技术类措施。在水土保持工 作中使用林草类技术措施就是通过植树 造林以及花草的栽种来开展相应的水土 保持工作, 这类方式的使用在提升植被 的覆盖率上有着十分显著的效果。在水 土保持和工作中土地生产力的维护也是
其中的主要措施之一, 主要是包括诸如 植树造林、封山育林等等方式, 通过这些 方式的使用就可以很好的将土壤的抓附 能力予以提升, 将土壤受到雨水侵蚀冲 刷的程度降至最低, 实现土壤稳定性的 显著提升。

\section{5 结语}

综上所述, 水土保持工作对水资源 和水环境的作用十分显著, 随着我国对 农业生产的不断重视, 农业的相关工作 也在顺利进行。经过上述介绍可以看出 水土保持工作可以充分发挥其积极效益, 增加水资源储蓄量, 解决水环境中出现 的各种复杂艰巨问题。水土保持的手段 也在不断改进、不断创新, 水土保持工作 也将显示出更大的积极效益。文章的介 绍为农业工作提供了有效的借鉴, 以期 水土保持工作更好地开展, 为我国农业 发展带来更大的效益。

\section{[参考文献]}

[1]何齐洁.水土保持对水资源量 与水质的影响探究 [J]. 现代农村科 技,2019,(02):90.

[2]王婷,马朵,刘思君,等.水土保持 措施对水资源与水环境的影响 [J].农业 与技术,2018,38(24):74-75.

[3]曾萍.水土保持对水资源与水质的影 响研究[J].科技资讯,2018,16(31):118+122. 